\title{
Achieving transformation through collaboration: the role of academic literacies
}

\author{
Ursula Wingate \\ King's College London, UK
}

\section{Abstract}

The academic literacies model has been transformative in the sense that it offered a new perspective for research into students' writing as well as pedagogic principles that have influenced writing practitioners in many contexts. In this paper I discuss why a more wideranging transformation is needed to provide adequate academic literacy support to all students. This transformation would entail the integration of academic literacy instruction into study programmes, delivered as part of subject lecturers' regular teaching and assessment practices. This would require collaboration between writing/learning development practitioners and subject lecturers, which in turn would need to be facilitated by changes in institutional policies and practices. I argue that the academic literacies model provides both the rationale and the principles for this kind of transformation.

Keywords: academic literacy instruction; student support; higher education policies and practices; genre approaches.

\section{Introduction}

Academic literacies emerged in the 1990s as a critical framework for the investigation of students' writing in the UK's higher education system. At a time when there was a substantial increase in student numbers and diversity, the model offered a new perspective on academic writing and exposed the inadequacy of the traditional student support measures. Since Lea and Street's (1998) seminal paper, academic literacies has had considerable impact on academic writing research and pedagogy in the UK and internationally. The model, which is based on ethnographic research, understands writing 
at university as social practices that are shaped by ideologies and institutional power relations. It critiques the conventional approaches, called 'study skills' and 'academic socialisation' by Lea and Street (1998), as these approaches tend to regard writing as a transferable skill and focus only on the linguistic and rhetorical features of texts, leading to a deficit view of students who are unable to produce texts according to the expected standards. In Lea and Street's (1998, p.158) view, academic literacies 'encapsulates' these approaches and builds on their insights.

Other scholars have taken a more dichotomous perspective, identifying academic literacies as the 'transformative' approach, as opposed to the (not clearly specified) 'normative' approaches (Lillis and Scott, 2007). The label 'normative' echoes with the critique of 'pragmatic English for Academic Purposes (EAP)', a term that has been used to describe the typical provision of academic English courses to non-native speakers of English (NNES). This provision has been accused of 'teaching students a set of dominant academic discourse norms' (Harwood and Hadley, 2004, p.356), to which they are expected to conform without criticality. Although this evaluation may be justified in relation to some teaching practices, a careful distinction must be made between this type of EAP work and genre-based instructional approaches, which seem to be included in the category 'normative'. Whilst these approaches require students to analyse genres to help them understand their disciplines' ways of communication, genre scholars have explicitly warned of prescribing norms and, at the same time, promoted the investigation of writing contexts and practices (e.g. Swales, 1990; Johns, 2008). Consequently, genre approaches have used ethnography not only as a research tool, but also as a teaching method, by which students are asked to explore the target discourse communities (e.g. Johns, 2008 and 2011; Motta-Roth, 2009). The labelling of genre approaches as normative has therefore been questioned by Wingate and Tribble (2012) and Flowerdew (2019), who point out that genre- as well as corpus-based research and pedagogy share common ground with academic literacies. As both paradigms have important contributions to make, i.e. the genre approaches with their clearly defined and successful teaching methodologies (see Pérez-Llantada and Swales, 2017, for an overview), and academic literacies with valuable insights from ethnographic studies (see the discussion in Lillis and Tuck, 2016), researchers and practitioners have advocated their convergence towards an academic literacy (reading and writing) pedagogy that is capable of transforming the current student support provision (Wingate and Tribble 2012; Hathaway, 2015; Flowerdew, 2019). A core element of this transformation must be that academic literacy instruction is available to all 
students instead of specific target groups on the premise that all students new to university are unfamiliar with the literacy practices of their academic disciplines.

A systematic provision of academic reading and writing support that is inclusive of all students does not exist in Anglophone universities. ${ }^{1}$ In many institutions, English language support is offered exclusively to 'international' students; for the rest of the student population, there may be a learning support unit available. Neither type of provision supports students in learning to understand and produce the genres used in their disciplines. This learning can only take place within the disciplines, or, more specifically, as an embedded component of study programmes. However, there are sparse examples of methodical integration of academic literacy support into study programmes (e.g. Purser, 2011). This leaves students largely dependent on individual subject lecturers' willingness and ability to provide support and, as a consequence, many students struggle far longer than necessary with the unfamiliar genres and conventions. Making academic literacy support an entitlement for all students by embedding it into study programmes would require a comprehensive transformation of institutional structures and practices. In the rest of this article, I want to consider the level of transformation achieved by academic literacies, as well as the importance of the model's principles for an institution-wide, or large-scale, transformation.

\section{The current transformative value of academic literacies}

Originally, Lillis and Scott (2007) assigned the label 'transformative' to academic literacies research on the basis that 'practice is privileged above text' (Lillis and Scott, 2007, p.10, italics in original) and ethnographic methods are used to explore practice. As Lillis (in Lillis et al., 2015, p.9) explains, unlike the 'normative' approaches, which are concerned with research questions such as '[w]hat is the nature of the writing required' with the aim to identify and then teach the required textual features, academic literacies researchers are interested in possible alternatives to traditional conventions of 'making knowledge', which would allow students to express meaning in ways with which they are more comfortable than with the genres imposed on them. However, at this point it is important to look more

\footnotetext{
1 The writing-intensive courses, which are part of the Writing across the Curriculum/Writing in the Disciplines (WAC/WID) programmes in universities in the USA and Canada, could be regarded as an inclusive provision. However, according to a survey on the state of WAC/WID in 2010 , only $51 \%$ of the responding 1,126 US and Canadian HE institutions had WAC/WID programmes (Thaiss and Porter, 2010).
} 
closely at the notion of 'transformative'. The critique of conventional norms and the search for alternatives are not directly transformative in my view; however, they have the potential to lead to changes in instructional policies and practices that in turn will lead to improvements in the student experience. I would therefore argue that critique and research can be facilitative of transformation, if they bring about institutional changes that would be directly transformative for students - in the sense that they receive support that helps them to do better. The next point to consider then is the extent of the transformation that can be triggered by research - does it facilitate instructional improvements for one or a few student groups in a specific context, a whole department, or a whole institution? As explained previously, given the lack of academic literacy support across the Anglophone higher education system, a wide-ranging transformation is necessary.

Academic literacies has over the years clearly achieved transformation in teaching practices, materials and curriculum design in numerous settings, and continues, as the articles in this volume show, to inspire teaching initiatives and interventions. Following earlier theory- and research-based recommendations for improvements in teaching and curriculum design (e.g. Lillis, 2001 and 2003; Lea, 2004), 31 chapters relating to 'transformative practice' in different disciplines and educational settings in 10 countries were presented in a recent volume edited by Lillis et al. (2015). The heading of each of the volume's four sections begins with 'transforming', relating to 'pedagogies of academic reading and writing', 'the work of teaching', 'resources, genres and semiotic practices', and 'institutional framings of academic writing' respectively. Of the 31 chapters, 19 present case studies of teaching interventions and curricular changes; these include raising the visibility of expected conventions and their hidden features, exploring disciplinary conventions through dialogue with subject lecturers, and encouraging students to draw on alternative semiotic resources. Whilst these case studies describe some innovative applications of academic literacies principles, from which other practitioners will take inspiration, at the same time they reveal that academic literacies has had limited impact in terms of wide-ranging institutional change. Apart from Jacobs (Chapter 9) and Boz (Chapter 25), who report some institutional impact achieved through collaborations with subject lecturers across a range of disciplines, and Cleary and O'Sullivan (Chapter 26) who created a writing centre for an Irish university, all the other cases present initiatives that are restricted to specific contexts and individual study programmes. 
Changes in institution-wide policies and practices are admittedly difficult to achieve; as Lillis (in Lillis et al., 2015, p.11) observes, 'working towards transformation in higher education is a large and challenging project, possible only through extensive collaboration'. In the final section, I will discuss the kind of collaboration necessary to move forward with a large-scale transformation of institutional policies and practices related to academic literacy instruction. I will also highlight the importance of academic literacies principles for this transformation.

\section{Working towards institution-wide transformation of academic literacy support}

As argued earlier, academic literacy instruction has to be embedded in study programmes to be inclusive of all students and to target their discipline-specific communication needs. The most effective provision would be if subject lecturers integrated academic literacy instruction into their regular teaching and assessment practices, and I have elsewhere discussed in more detail various methods for this integration (Wingate, 2015). Examples would be lecturers dedicating some lecture time to discussions about academic literacy requirements or using feedback more purposefully to help students address shortcomings in their reading and writing. However, as subject lecturers often have only a 'tacit' (Jacobs, 2005, p.477) knowledge of their discipline's discourses, they would rely on collaboration with experts in academic language and learning, that is EAP and learning development staff. This collaboration would require structural changes, for instance in workload allocations and the position of EAP and learning development specialists in the institution. Since it is unlikely that university managements would implement such changes without evidence of their benefits, they can only be realised through bottom-up work that is based on sound educational principles and teaching methodologies. This work would entail EAP and learning development units seeking closer collaboration with academic departments, supporting increasing numbers of lecturers in integrating academic literacy support into their regular routines, continuously evaluating and improving this approach, and disseminating successful practice across the university.

A number of EAP and learning development units in universities in the UK, Australia and South Africa have long collaborated with staff in the disciplines (e.g. Thesen and van Pletzen 2006; Morley, 2008) and, judging from recent conference contributions (for 
instance at the BALEAP PIM Conference in March 2016 and the BALEAP Conference in April 2019), this type of collaboration is on the increase. Whilst many of the practitioners involved are guided by academic literacies principles, I would argue that the main teaching approach should be genre-based. As mentioned earlier, genre approaches have effective teaching methods, the most prominent of which is to ask students to analyse the genres they will have to write. Genre pedagogy has therefore long been recognised as transformative or 'empowering' (Hyland, 2004, p.15), since it accelerates students' participation in disciplinary communication. And despite its previous critique of EAP/Genre, it is the Academic Literacies model that provides much of the rationale not only for embedding academic literacy instruction into the disciplines, but also for using genre pedagogy.

An important academic literacies principle, proposed by Lillis (2003), is to take a dialogic approach to student writing by providing 'talkback' rather than feedback. A dialogue about texts in progress would be most transformative if it was conducted between the subject lecturer who sets and assesses the assignment and the students who need to understand how to meet the assignment requirements. Another principle, that of 'exploring alternative ways of meaning making in academia' (Lillis and Scott, 2007, p.13) or opening up 'the academy to a broader range of semiotic/linguistic practices' (Lillis and Tuck, 2016, p.35) can also be followed through dialogue between subject lecturers and their students. In such dialogues, facilitated through the embedding of academic literacy support in study programmes, negotiation about alternatives to the required genres would undoubtedly occur. A concept that supports the use of genre pedagogy is Lillis's (2001, p.58) 'institutional practice of mystery'. Much of the mystery students experience is around the unfamiliar genres in which they are required to express themselves. Without genre purpose and features being made explicit, the mystery becomes misery for many students, because they are assessed on the adequate production of these genres. Developing students' 'genre awareness' (Johns, 2011) should therefore be the central objective of embedded academic literacy instruction. In this process, students will also learn to recognise genres as 'problem spaces open to critique and challenge' (Johns, 2011, p.61).

The discussion has shown that transformation of university policies and practices is needed to transform the experience of whole student cohorts. Change can be initiated through closer collaboration between EAP and learning specialists and subject lecturers. It 
also requires the collaboration of the proponents of different paradigms to make a strong case for embedding academic literacy instruction into the disciplines..

\section{References}

Flowerdew, L. (2019) 'The academic literacies approach to scholarly writing: A view through the lens of the ESP/Genre approach', Studies in Higher Education. Available at: https://doi.org/10.1080/03075079.2019.1576165 (Accessed: 3 November 2019).

Harwood, N. and Hadley, G. (2004) ‘Demystifying institutional practices: Critical pragmatism and the teaching of academic writing', Journal of English for Specific Purposes 23, pp.355-377.

Hathaway, J. (2015) 'Developing that voice: Locating academic writing tuition in the mainstream of higher education', Teaching in Higher Education 20, pp.506-517.

Hyland, K. (2004) Genre and Second Language Writing. Ann Arbor, Michigan: University of Michigan Press.

Jacobs, C. (2005) 'On being an insider on the outside: new spaces for integrating academic literacies', Teaching in Higher Education 10(4), pp.475-487.

Johns, A. M. (2008) 'Genre awareness for the novice academic student: an ongoing quest', Language Teaching 41(2), pp.237-252.

Johns, A. M. (2011) 'The future of genre in L2 writing: Fundamental, but contested, instructional decisions', Journal of Second Language Writing 20, pp.56-68.

Lea, M. (2004) 'Academic literacies: A pedagogy for course design', Studies in Higher Education 29(6), pp.739-756.

Lea, M. and Street, B. (1998) 'Student writing in higher education: An Academic Literacies approach', Studies in Higher Education 23(2), pp.157-172. 
Lillis, T. (2001) Student Writing: Access, Regulation, Desire. London: Routledge.

Lillis, T. (2003) 'Student writing as "Academic Literacies": Drawing on Bakhtin to move from critique to design', Language and Education 17(3), pp.192-207.

Lillis, T. and Scott, M. (2007) 'Defining Academic Literacies research: Issues of epistemology, ideology and strategy', Journal of Applied Linguistics 4(1), pp.5-32.

Lillis, T., Harrington, K., Lea, M. and Mitchell, S. (eds) (2015) Working with Academic Literacies: Case Studies towards Transformative Practice. Fort Collins, Co: The WAC Clearinghouse/Parlor Press.

Lillis. T. and Tuck, J. (2016) 'Academic Literacies: A critical lens on writing and reading in the academy', in Hyland, K. (ed.) The Routledge Handbook of English for Academic Purposes. Abingdon, New York: Routledge, pp.30-43.

Morley, J. (2008) 'Writing support in British higher education: An institutional case study', in Friedrich, P. (ed.) Teaching Academic Writing. London: Continuum, pp.125-146.

Motta-Roth, D. (2009) 'The role of context in academic text production and writing pedagogy', in Bazerman, C., Bonini, A. and Figueiredo, D. (eds.) Genre in a Changing World. Fort Collins, Co: The WAC Clearinghouse/Parlor Press, pp.317336.

Pérez-Llantada, C. and Swales, J. (2017) 'English for Academic Purposes', in Hinkel, E. (ed.) Handbook of Research in Second Language Teaching and Learning, vol. III. Abingdon, New York: Routledge, pp.42-55.

Purser, E. (2011) 'Developing academic literacy in context: Trends in Australia', in Deane, M. and O'Neill, P. (eds.) Writing in the Disciplines. London: Palgrave Macmillan, pp.30-43.

Swales, J. M. (1990) Genre analysis: English in academic and research settings. Cambridge: Cambridge University Press. 
Thaiss, C. and Porter, T. (2010) 'The state of WAC/WID in 2010: Methods and results of the U.S. survey of the international WAC/WID mapping project', College Composition and Communication 61(3), pp.534-570.

Thesen, L. and van Pletzen, E. (eds.) (2006) Academic literacy and the languages of change. London, New York: Continuum.

Wingate, U. (2015) Academic literacy and student diversity. The case for inclusive practice. Bristol: Multilingual Matters.

Wingate, U. and Tribble, C. (2012) 'The best of both worlds? Towards an English for Academic Purposes/Academic literacies writing pedagogy', Studies in Higher Education 37(4), pp.481-495.

\section{Author details}

Ursula Wingate is Reader in Language in Education and works in the School of Education, Communication and Society at King's College London. Ursula's research interests are in academic literacy, English language policies and practices, and language teaching methodology. Her recent publications are concerned with the teaching and learning of argumentation, genre-based approaches to academic literacy instruction, and dialogic interaction in academic writing tutorials.. 